\author{
Geology and geophysics
}

http://www.journalesgia.com

\title{
DYNAMIC TRIGGERING OF MUD VOLCANOS IN AZERBAIJAN BY CASPIAN EARTHQUAKES
}

\author{
Babayev G. ${ }^{1}$, Kadirov F. ${ }^{1}$, Tibaldi A. ${ }^{2}$, Bonali F. ${ }^{2}$, Aliyev Y. ${ }^{1}$ \\ ${ }^{1}$ Institute of Geology and Geophysics, Azerbaijan National Academy of Sciences \\ 119, H. Javid Ave., Baku, AZ1143, Azerbaijan: babayev74@gmail.com \\ 2 University of Milan Bicocca, \\ 4, Piazza della Scienza, Milan, 20126, Italy
}

Keywords: earthquake, triggering mechanism, mud volcano, dynamic stress, Azerbaijan
Summary. There are several viewpoints about the relationship of mud volcano eruptions with earthquakes, or earthquake occurrences with mud volcano eruptions. This paper demonstrates evaluation of dynamic strains triggered by Caspian earthquakes which occurred on the $25^{\text {th }}$ of November, 2000, south of Baku city with $\mathrm{M}_{\mathrm{w}} 6.1$ and 6.2. Consequently, we researched the relationship between seismic regime and mud volcano eruptions in Azerbaijan located in ShamakhiGobustan-Absheron. We investigated over 30 mud volcanoes with over $100 \mathrm{~km}$ distance from near epicentres of Caspian earthquakes in terms of time within five years before and after Caspian earthquakes in 2000. As a result of computation, dynamic strain demonstrates that all the volcanoes in the study area are affected mostly by Caspian earthquake-induced transient strain. A larger number of mud eruptions occurred at a distance greater than 50-60 km from the 2000 Caspian epicentres. Mud volcanoes were erupted within 2-3 years at the range of 40 and $110 \mathrm{~km}$ from the epicentres. After three years from earthquake occurrence in Caspian Sea, mud volcanoes were erupted at the distance more than $70 \mathrm{~km}$. The largest number of eruptions occurred within two years from the earthquakes, in particular the highest frequency is within six months. In particular, several eruptions occurred within 8 months from the shock, after this period the number of eruption for months is more scattered and discontinuous The comparison made us conclude that dynamic stresses are predominantly interlinked with triggering demonstrating higher magnitude, and consequently eruptions are favored up to 1-2 years following the earthquakes.

(C) 2019 Earth Science Division, Azerbaijan National Academy of Sciences. All rights reserved.

\section{Introduction}

The relationship between mud volcano eruptions and earthquake occurrences has been studied for years. Researches demonstrate that mud volcanoes erupt quickly or periodically after earthquakes occur with the epicenters locating closely (Manga et al., 2009). Many studies were done researching the triggering mechanism of magma eruptions by earthquake (Linde and Sacks, 1998; Nostro et al., 1998; Walter and Amelung, 2007; Eggert and Walter, 2009; Walter et al., 2009; Watt et al., 2009; Bonali et al., 2013) and this effect was observed also in terms of mud volcanos in recent years (Mellors et al., 2007).

Azerbaijan is well-known worldwide with 190 mud volcanoes on land, a few tens of kilometers from the capital Baku, and other 150 offshore in the Caspian Sea (Guliyev and Feyzullayev, 1997; Kad- irov, Mukhtarov, 2004; Aliyev et.al., 2009; Feyzullayev, 2012; Babayev et.al., 2014; Aliyev et. al., 2015). Azerbaijan mud volcanoes are preserved as natural phenomenon in line with representing a threat to the infrastructure in Baku, small villages nearby Baku city, roads, critical objects (e.g., pipelines) and buildings. Mud volcanoes have been considered to be linked to the ongoing tectonics for what concerns both fault activity which may guide the rate of mud extrusion (Kopf, 2008) and the state of stress that dictates the volcano shape and vent distribution (Bonini and Mazzarini, 2010; Bonini, 2012). Theoretically mud volcanoes are mostly located in compressional belts, have several morphological and structural similarities with lava volcanoes and thus represent a good proxy to analyze the feeding systems under contractional tectonics $(\mathrm{Gu}-$ liyev and Feyzullayev, 1997; Kadirov, Mukhtarov, 
2004; Aliyev et.al., 2009; Feyzullayev, 2012; Babayev et.al., 2014; Aliyev et. al., 2015). For all these reasons the study of the relationships between tectonics and mud volcanism is an important recent task of research and more work is still necessary to unravel the complex picture (Tibaldi, 2008; Tibaldi et al., 2010).

The principal aim of the present study was to research the relationship between seismic regime and mud volcano eruptions in Azerbaijan located in Shamakhi-Gobustan-Absheron, following two earthquakes with $\mathrm{M}_{\mathrm{w}} 6.1$ and 6.2 occurred in the Caspian Sea on November 25, 2000, south of Baku city (Fig. 1). For that we applied the influential mechanism of dynamic strain changes triggered by those Caspian earthquakes on the activity of volcanos close to the earthquake epicenters.

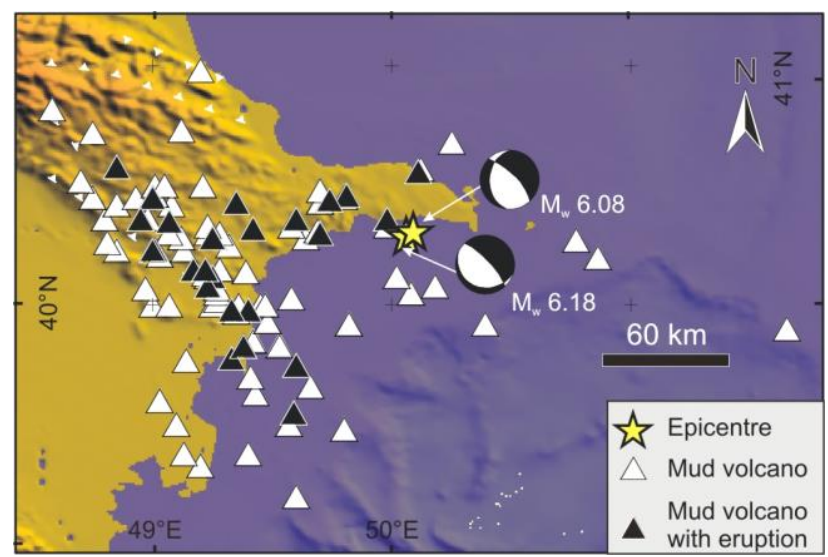

Fig. 1. Study area with distribution of mud volcanoes and location of the studied earthquakes of November 25, 2000

\section{Seismicity}

The study area Shamakhi-Gobustan-Absheron is close to the epicentres of Caspian earthquakes. Greater and Lesser Caucasus is the main orogen (Alizadeh et. al., 2017) of the Azerbaijan earthquake-prone country. Azerbaijan itself is situated in the active continent collision of the ArabianEurasian plates and involved in dynamics of lithospheric structural units of those plates. The ArabianEurasian collision continues to be accommodated by lithospheric shortening and lateral displacement of lithosphere out of the collision zone along the rightlateral strike-slip faults (Reilinger et. al., 2006; Kadirov et. al., 2012; Alizadeh et. al., 2017). These regional tectonic processes give rise to earthquakes that have devastated the Caucasus region (Babayev et.al., 2014). Since earthquakes result from stress concentrations at zones of weakness, one approach to advance the level of hazard assessment is to perform geodynamic numerical models to compute stress concentrations within the crust.The ongoing regional tectonic processes and lithosphere defor- mations produced earthquakes that have devastated the Caucasus region also during recent historic times (e.g. the 1902 Shamakhi earthquake; Veber, 1904). The Absheron peninsula together with its offshore part (the Azerbaijan sector of the Caspian Sea) is located in the south-eastern extremity of the Greater Caucasus, where the orogenic active processes still occur (Babayev et.al., 2014). Earthquakes in the region migrate along the Alpine-Himalayan seismic belt (Ismail-Zadeh, 1996) and are associated with the fault zones located in the Absheron peninsula (Fig. 1). Whereas the Gobustan zone can be considered even aseismic based on the available data, the Absheron peninsula is affected by low-magnitude but frequent earthquakes (Telesca et. al., 2012). The larger potential threat to the Absheron peninsula comes from the earthquakes originating under the Caspian Sea. The Caspian Sea in fact is another seismically-active zone of Azerbaijan; the seismicity is mostly crustal (depths typically $<30 \mathrm{~km}$ ), although events as deep as $80 \mathrm{~km}$ have been reported and may represent incipient subduction across the midCaspian (Jackson et al., 2002). November 25, 2000 earthquakes of $\mathrm{M}_{\mathrm{w}} 6.2$ band 6.081, which occurred in the Caspian Sea close to Baku city (Fig. 1), were characterized by focal depths of 40 and $33 \mathrm{~km}$ respectively (Jackson et al., 2002).

\section{Eruptions following the November 25, 2000 earthquakes}

After the two earthquakes of 2000, 33 eruptions occurred at 24 different mud volcanoes within a maximum distance of $108 \mathrm{~km}$ from the epicentres (Fig. 2).

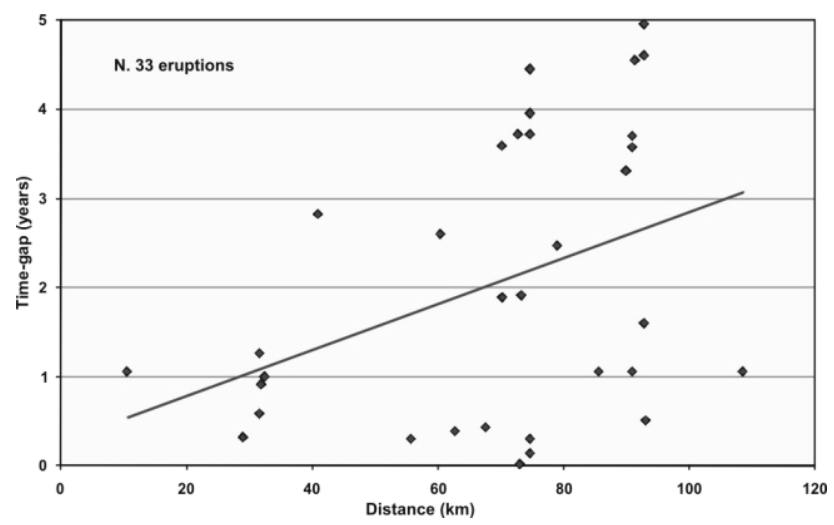

Fig. 2. Eruptions occurred in the five years following the studied earthquakes: time-gap versus averaged distance from the 2000 earthquake epicentres

A larger number of mud eruptions occurred at a distance greater than $50-60 \mathrm{~km}$ from the epicentres (Fig. 3A). The largest number of eruptions occurred within two years from the earthquakes, in particular the highest frequency is within six months (Fig. 3B). 
It is also possible to see that 6 eruptions occurred within 1.5 year from the earthquake at a distance $<40 \mathrm{~km}$ (Fig. 2). Eruptions within 2-3 years occurred at a distance between 40 and $110 \mathrm{~km}$ from the epicentres, on the contrary eruptions after 3 years occurred only at a distance greater than $70 \mathrm{~km}$ (Babayev et al., 2014). In particular, several eruptions occurred within 8 months from the shock, after this period the number of eruption for months is more scattered and discontinuous (Fig. 4).
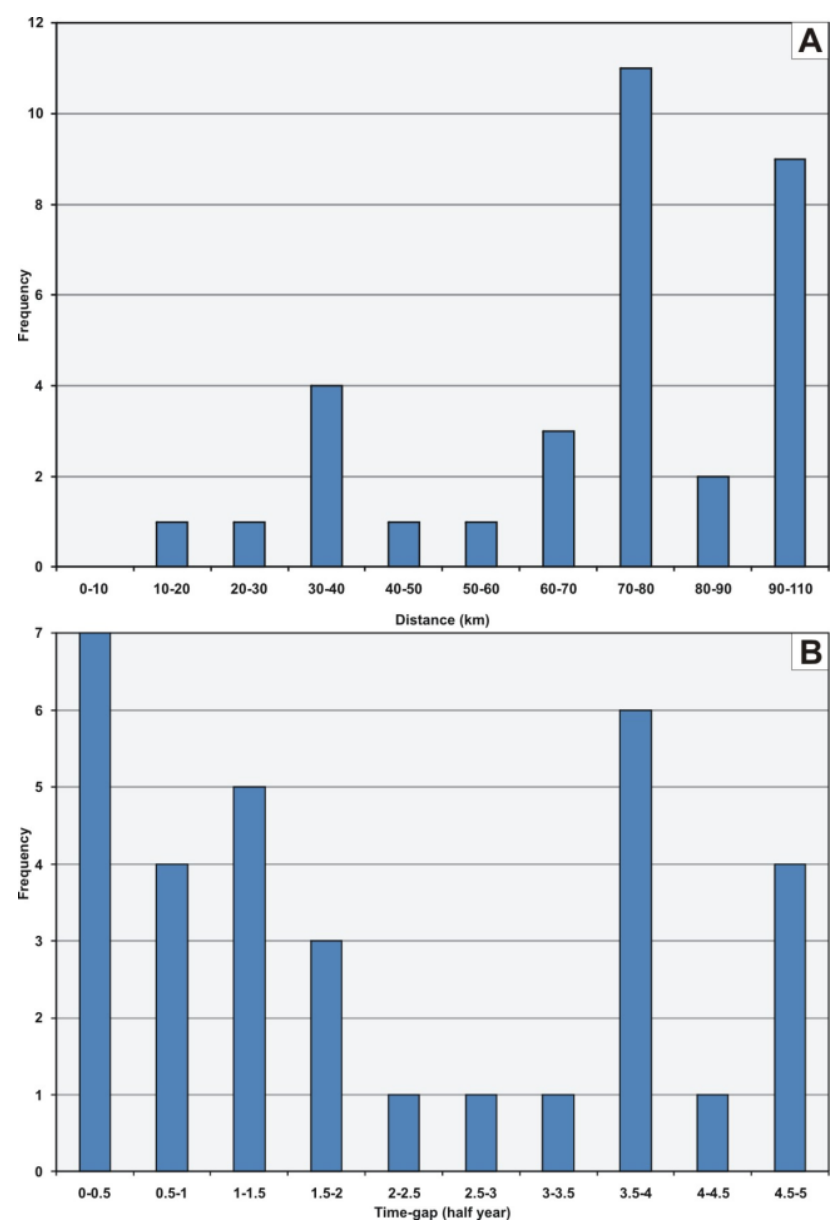

Fig. 3. Frequency of eruptions occurred in the five years following the studied earthquakes plotted versus (A) distance from the epicentres and (B) time-gap. The data have been classified in 10 classes

\section{Method for dynamic strain}

An earthquake generates also dynamic perturbations (Hill et al., 2002; Manga and Brodsky, 2006). Seismic waves travel at great distances without losing much of their energy (Hill et al., 2002) and dynamic stress change decreases more slowly than static stress change (Hill and Prejean, 2007). We estimated the peak transient strain applying the formula $\varepsilon=\mathrm{PGV} / \mathrm{V}_{\mathrm{s}}$, where $\varepsilon$ is strain amplitude and $\mathrm{V}_{\mathrm{s}}$ is the shear wave velocity (Manga et al., 2009) assumed equal to $2500 \mathrm{~m} / \mathrm{s}$ (Kanno et al., 2006) and PGV is the Peak Ground Veloci- ty, although we are aware of some uncertainty of this method because it does not account for the earthquake focal mechanism (Babayev et al., 2014) or the effect of directivity and approximates rupture location by the hypocenter (Manga et al., 2009).

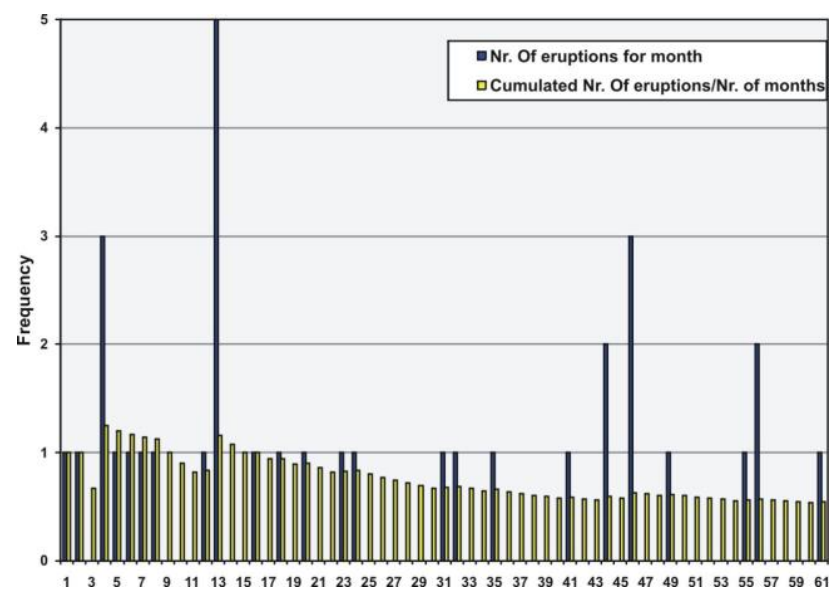

Fig. 4. Eruptions occurred in the five years following the studied earthquakes: it is reported the number of eruptions per month (blue) and the cumulative number per month/number of months (yellow)

The PGV values for the studied mud volcano region have been estimated using the relationship between moment magnitude of the events $\left(\mathrm{M}_{\mathrm{w}} 6.1\right.$ and $\mathrm{M}_{\mathrm{w}} 6.2$ ) and the epicentral distance $\mathrm{R}$ (in $\mathrm{km}$ ). The equation by Akkar and Bommer (2010) was derived from the data of Europe, Mediterranean and Middle East. The selected equation for PGV is well-suited for our study area with soft to hard bedrocks, typical for the site conditions of the Shamakhi-Gobustan-Absheron region of Azerbaijan (Babayev et. al., 2010). Using the PGV values at bedrock as the seismic input motion parameters, all dynamic parameters of both subsurface soil and the surface PGA (Peak Ground Acceleration) can be determined (Babayev et al., 2010). Site effects, detailed surface geology, the amplification factor and the seismic response of subsurface soils have been analyzed to illustrate the influence of the siteeffects terms and determine the surface motion velocity for the mud volcanoes in the study area (Babayev et al., 2014).

\section{Results}

Computation of dynamic strain demonstrates that all the volcanoes in the researched area are affected by Caspian earthquake-induced transient strain (Fig. 5). The magnitude of dynamic effects decreases with distance from the epicenters (Fig. $5 \mathrm{~A}$ ), while the time-gap increases with a decrease in earthquake-induced dynamic strains (Fig. 5B). 

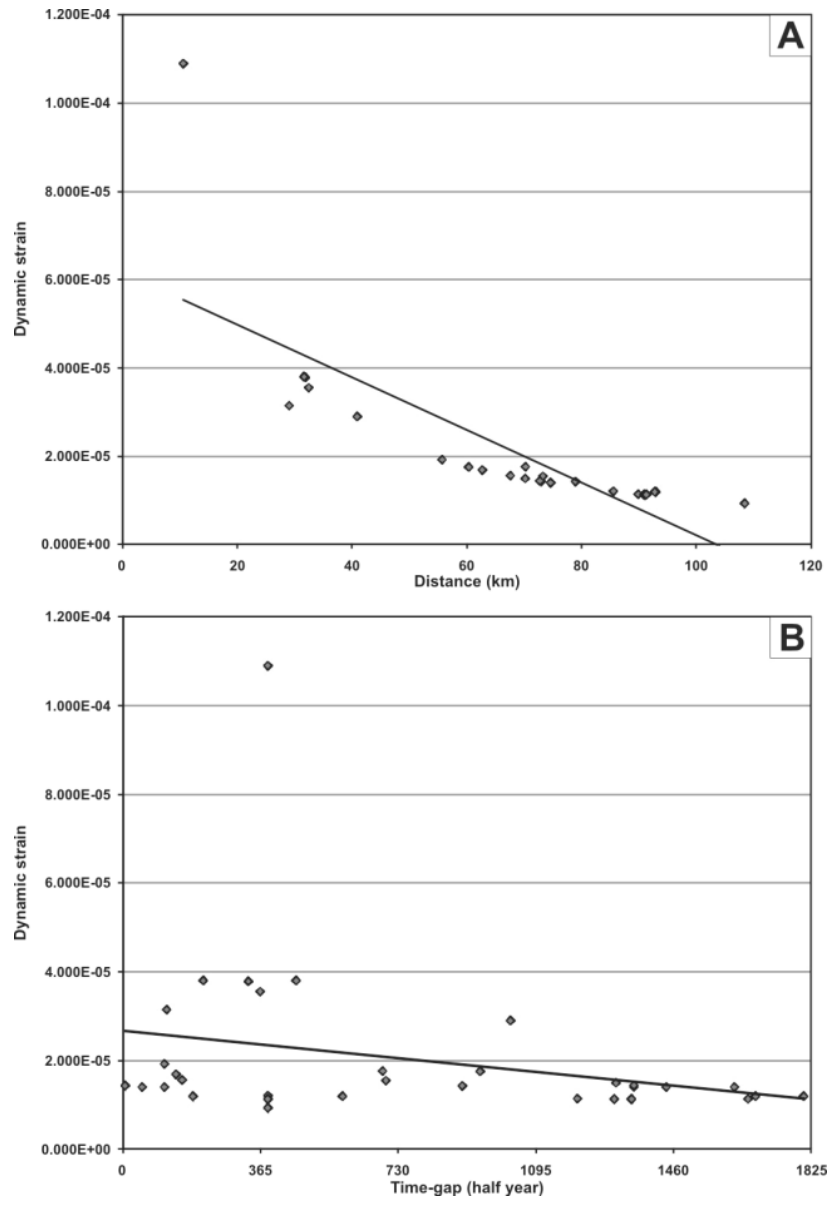

Fig. 5. Cumulated dynamic strain demonstrating the dependency of the distance from the epicentres (a) and the time delay (b). The dots represent mud volcanoes in the study area

\section{Discussion}

Theoretically dynamic stress changes also decrease more slowly with distance making them a more effective triggering agent at long distances (Mellors et al., 2007). Mud volcanoes are commonly thought to be sourced from deep, highly overpres-

\section{REFERENCES}

Akkar S., Bommer J. Empirical equations for the prediction of PGA, PGV, and spectral accelerations in Europe, the Mediterranean Region, and the Middle East. Seismological Research Letters, V. 81, No. 2, 2010, pp. 195-206.

Aliyev A., Guliyev I., Dadashov F., Rahmanov R. Atlas of the world mud volcanoes. Nafta-Press. Sandro Teti Editor $2015,322 \mathrm{p}$.

Aliyev A.A., Guliyev I.S., Rakhmanov R.R. Catalogue of mud volcano eruptions of Azerbaijan (1810-2001 yrs). NaftaPress. 2009, 110 p.

Alizadeh A., Guliyev I., Kadirov F., Eppelbaum L. Geosciences of Azerbaijan. Volume II: Economic geology and applied geophysics. Springer International Publishing. Switzerland, 2017, 348 p. DOI: 10.1007/978-3-319-40493-6.

Babayev G., Ismail-Zadeh A., Le Moüel J.-L. Scenario-based earthquake hazard and risk assessment for Baku (Azerbaijan). Nat. Hazards Earth Syst. Sci., V. 10, 2010, pp. 2697-2712.

Babayev G., Tibaldi A., Bonali F., Kadirov F. Evaluation of earthquake-induced strain in promoting mud eruptions: the sured shales (e.g., diapirs), liquefaction of clays, or shallow overpressured gas, hydrate, or water-rich sequences (Brown, 1990; Galli, 2000; Kopf, 2002). A trigger effect is the final step that precedes the manifestation or the initiation of an eruption (Mazzini et al., 2009). Based on our results, in the 5 years following the two 2000 Azerbaijan earthquakes, 33 eruptions occurred at a maximum distance of about $108 \mathrm{~km}$ from these seismic events. The first eruption occurred after 6 days and 19 eruptions occurred within 2 years (Babayev et al., 2014). Out of 33 mud volcano eruptions researching in the current study 26 mud volcanoes are implied to be dynamicallytriggered by Caspian earthquakes, and the rest seven eruptions are triggered not only by dynamic stress change.

\section{Conclusion}

In conclusion it can be stated that after two earthquakes of 2000, 33 eruptions occurred at 24 different mud volcanoes within a maximum distance of over $100 \mathrm{~km}$ from the epicentres, while a significant number of mud eruptions occurred at a distance larger than 50$60 \mathrm{~km}$ from the epicentres. In addition, the largest number of eruptions occurred within two years from the earthquakes, in particular within six months. After this period the number of eruption for months is scattered and discontinuous, although a large number of eruptions occurred 13 months after the earthquake. Dynamic strain is observed in all researched eruptions. Besides, the analysis of the research revealed that the eruption was intensified within five years after the Caspian earthquake occurrences in 2000. This time delay might happen due to the complexity and various mechanisms that are manifested in the substratum at the plumbing system in the mud volcano.

\section{ЛИТЕРАТУРА}

Akkar S., Bommer J. Empirical equations for the prediction of PGA, PGV, and spectral accelerations in Europe, the Mediterranean Region, and the Middle East. Seismological Research Letters, V. 81, No. 2, 2010, pp. 195-206.

Aliyev A., Guliyev I., Dadashov F., Rahmanov R. Atlas of the world mud volcanoes. Nafta-Press. Sandro Teti Editor. 2015, $322 \mathrm{p}$.

Aliyev A.A., Guliyev I.S., Rakhmanov R.R. Catalogue of mud volcano eruptions of Azerbaijan (1810-2001 yrs). NaftaPress. 2009, 110 p.

Alizadeh A., Guliyev I., Kadirov F., Eppelbaum L. Geosciences of Azerbaijan. Volume II: Economic geology and applied geophysics. Springer International Publishing. Switzerland, 2017, 348 p. DOI: 10.1007/978-3-319-40493-6.

Babayev G., Ismail-Zadeh A., Le Moüel J.-L. Scenario-based earthquake hazard and risk assessment for Baku (Azerbaijan). Nat. Hazards Earth Syst. Sci., V. 10, 2010, pp. 2697-2712.

Babayev G., Tibaldi A., Bonali F., Kadirov F. Evaluation of earthquake-induced strain in promoting mud eruptions: the 
case of Shamakhi-Gobustan-Absheron areas, Azerbaijan. Natural hazards, V. 72, No. 2, 2014, pp. 789-808.

Bonali F.L., Tibaldi A., Corazzato C., Tormey D.R., Lara L.E. Quantifying the effect of large earthquakes in promoting eruptions due to stress changes on magma pathway: The Chile case. Tectonophysics, V. 583, 2013, pp. 54-67.

Bonini M. Mud volcanoes: Indicators of stress orientation and tectonic controls. Earth-Science Reviews, V. 115, No. 3, 2012, pp. 121-152.

Bonini M., Mazzarini F. Mud volcanoes as potential indicators of regional stress and pressurized layer depth. Tectonophysics, V. 494, 2010, pp. 32-47.

Brown K.M. The nature and hydrogeologic significance of mud diapirs and diatremes for accretionary systems. Journal of Geophysical Research, V. 95, No. B6, 1990, pp. 8969-8982.

Eggert S., Walter T.R. Volcanic activity before and after large tectonic earthquakes: Observations and statistical significance. Tectonophysics, V. 471, No.1-2, 2009, pp. 14-26, DOI:10.1016/j.tecto.2008.10.003.

Feyzullayev A.A. Mud volcanoes in the South Caspian basin: Nature and estimated depth of its products. Natural Science, V. 4, No. 7, 2012, pp. 445-453, DOI:10.4236/ns.2012.4706.

Galli P. New empirical relationships between magnitude and distance for liquefaction: Tectonophysics, V. 324, No. 3, 2000, pp. 169-187.

Guliyev I.S., Feyzullayev A.A. All about mud volcanoes. Nafta Press. Baku, 1997, 52 p.

Hill D.P., Pollitz F., Newhall C. Earthquake-volcano interactions. Physics Today, V. 55, No. 11, 2002, pp. 41-47.

Hill D.P., Prejean S. Dynamic triggering. In: Earthquake Seismology (ed. H.Kanamori), V. 4, 2007, pp. 258-288. Treatise on Geophysics (ed. in chief G.Schubert), Elsevier. Amsterdam.

Ismail-Zadeh A. Migration of seismic activity in the Caspian Sea. In: Computational seismology and geodynamics (ed. Chowdhury D.K.). V. 3. American Geophysical Union, Washington D.C. 1996, pp. 125-129.

Jackson J., Priestley K., Allen M., Berberian M. Active tectonics of the South Caspian Basin. Geophys. J. Int., V. 148, No. 2 , 2002, pp. 214-245.

Kadirov F.A., Mukhtarov A.Sh. Deep structure and dynamics of the Lokbatan mud volcano. Izvestiya, Physics of the Solid Earth (Fizika zemli), V. 40, No. 4, 2004, pp. 327-333.

Kadirov F.A., Floyd M.A., Alizadeh A., Guliev I., Reilinger R.E., Kuleli S., King R.W., Toksoz M.N. Kinematics of the Caucasus near Baku, Azerbaijan, J. Nat. Hazards, V. 63, 2012, pp. 997-1006, DOI: 10.1007/s11069-012-0199-0.

Kanno T., Narita A., Morikawa N., Fujiwara H., Fukushima Y. A new attenuation relation for strong ground motion in Japan based on recorded data. Bulletin of the Seismological Society of America, V. 96, No. 3, 2006, pp. 879-897.

Kopf A.J. Significance of mud volcanism. Reviews of Geophysics, V. 40, No. 2, 2002, pp. 2.1-2.52, DOI: 10.1029/2000RG000093.

Kopf A.J. Making calderas from mud. Nature Geoscience, V. 1, 2008, pp. 500-501.

Linde A.T., Sacks I.S. Triggering of volcanic eruptions. Nature, V. 395, 1998, pp. 888-890.

Manga M., Brumm M., Rudolph M.L. Earthquake triggering of mud volcanoes. Marine and Petroleum Geology, V. 26, No. 9, 2009, pp. 1785-1798.

Manga M., Brodsky E. Seismic triggering of eruptions in the far field: Volcanoes and geysers: Annual Review of Earth and Planetary Sciences, V. 34, No. 1, 2006, pp. 263-291, DOI: 10.1146/annurev.earth.34.031405.125125.

Mazzini A., Nermoen A., Krotkiewski M., Podladchikov Y., Planke S., Svensen H. Strike-slip faulting as a trigger mechanism for overpressure release through piercement structures. Implications for the Lusi mud volcano, Indo- case of Shamakhi-Gobustan-Absheron areas, Azerbaijan. Natural hazards, V. 72, No.2, 2014, pp. 789-808.

Bonali F.L., Tibaldi A., Corazzato C., Tormey D.R., Lara L.E. Quantifying the effect of large earthquakes in promoting eruptions due to stress changes on magma pathway: The Chile case. Tectonophysics, V. 583, 2013, pp. 54-67.

Bonini M. Mud volcanoes: Indicators of stress orientation and tectonic controls. Earth-Science Reviews, V. 115, No. 3, 2012, pp. 121-152.

Bonini M., Mazzarini F. Mud volcanoes as potential indicators of regional stress and pressurized layer depth. Tectonophysics, V. 494, 2010, pp. 32-47.

Brown K.M. The nature and hydrogeologic significance of mud diapirs and diatremes for accretionary systems. Journal of Geophysical Research, V. 95, No. B6, 1990, pp. 8969-8982.

Eggert S., Walter T.R. Volcanic activity before and after large tectonic earthquakes: Observations and statistical significance. Tectonophysics, V. 471, No.1-2, 2009, pp. 14-26, DOI:10.1016/j.tecto.2008.10.003.

Feyzullayev A.A. Mud volcanoes in the South Caspian basin: Nature and estimated depth of its products. Natural Science, V. 4, No. 7, 2012, pp. 445-453, DOI:10.4236/ns.2012.4706.

Galli P. New empirical relationships between magnitude and distance for liquefaction: Tectonophysics, V. 324, No. 3, 2000, pp. 169-187.

Guliyev I.S., Feyzullayev A.A. All about mud volcanoes. Nafta Press. Baku, 1997, 52 p.

Hill D.P., Pollitz F., Newhall C. Earthquake-volcano interactions. Physics Today, V. 55, No. 11, 2002, pp. 41-47.

Hill D.P., Prejean S. Dynamic triggering. In: Earthquake Seismology (ed. H.Kanamori), V. 4, 2007, pp. 258-288. Treatise on Geophysics (ed. in chief G.Schubert), Elsevier. Amsterdam.

Ismail-Zadeh A. Migration of seismic activity in the Caspian Sea. In: Computational seismology and geodynamics (ed. Chowdhury D.K.). V. 3. American Geophysical Union, Washington D.C. 1996, pp. 125-129.

Jackson J., Priestley K., Allen M., Berberian M. Active tectonics of the South Caspian Basin. Geophys. J. Int., V. 148, No. 2, 2002, pp. 214-245.

Kadirov F.A., Mukhtarov A.Sh. Deep structure and dynamics of the Lokbatan mud volcano. Izvestiya, Physics of the Solid Earth (Fizika zemli), V. 40, No. 4, 2004, pp. 327-333.

Kadirov F.A., Floyd M.A., Alizadeh A., Guliev I., Reilinger R.E., Kuleli S., King R.W., Toksoz M.N. Kinematics of the Caucasus near Baku, Azerbaijan, J. Nat. Hazards, V. 63, 2012, pp. 997-1006, DOI: 10.1007/s11069-012-0199-0.

Kanno T., Narita A., Morikawa N., Fujiwara H., Fukushima Y. A new attenuation relation for strong ground motion in Japan based on recorded data. Bulletin of the Seismological Society of America, V. 96, No. 3, 2006, pp. 879-897.

Kopf A.J. Significance of mud volcanism. Reviews of Geophysics, V. 40, No. 2, 2002, pp. 2.1-2.52, DOI: 10.1029/2000RG000093.

Kopf A.J. Making calderas from mud. Nature Geoscience, V. 1, 2008, pp. 500-501.

Linde A.T., Sacks I.S. Triggering of volcanic eruptions. Nature, V. 395, 1998, pp. 888-890.

Manga M., Brumm M., Rudolph M.L. Earthquake triggering of mud volcanoes. Marine and Petroleum Geology, V. 26, No. 9, 2009, pp. 1785-1798.

Manga M., Brodsky E. Seismic triggering of eruptions in the far field: Volcanoes and geysers: Annual Review of Earth and Planetary Sciences, V. 34, No. 1, 2006, pp. 263-291, DOI: 10.1146/annurev.earth.34.031405.125125.

Mazzini A., Nermoen A., Krotkiewski M., Podladchikov Y., Planke S., Svensen H. Strike-slip faulting as a trigger mechanism for overpressure release through piercement structures. Implications for the Lusi mud volcano, Indo- 
nesia. Marine and Petroleum Geology, V. 26, No. 9, 2009, pp. 1751-1765.

Mellors R., Kilb D., Aliyev A., Gasanov G., Yetirmishli G. Correlations between earthquakes and large mud volcano eruptions: Journal of Geophysical Research, V. 112, No. B04304, 2007, DOI: 10.1029/2006JB00448.

Nostro C., Stein R.S., Cocco M., Belardinelli M.E., Marzocchi W. Two-way coupling between Vesuvius eruptions and southern Apennine earthquakes, Italy, by elastic stress transfer. Journal of Geophysical Research, V. 103, No. B10, 1998, pp. 24,487-24,504.

Reilinger R.E., McClusky S.C., Vernant P., Lawrence S., Ergintav S., Cakmak R., Ozener H., Kadirov F., Guliev I., Stepanian R., Nadariya M., Hahubia G., Mahmoud S., Sakr K., Arrajehi A., Paradissis D., Al-Aydrus A., Prilepin M., Guseva T., Evren E., Dmirotsa A., Filikov S.V., Gomez F., Al-Ghazzi R., Karam G. GPS constraints on continental deformation in the Africa-Arabia-Eurasia continental collision zone and implications for the dynamics of plate interactions. Journal of Geophysical Research, V. 111, No. B5, 2006, DOI: 10.1029/2005JB004051.

Telesca L., Babayev G., Kadirov F. Temporal clustering of the seismicity of the Absheron-Prebalkhan region in the Caspian Sea area. Nat. Hazards Earth Syst. Sci., V. 12, No. 11, 2012, pp. 3279-3285, DOI:10.5194/nhess-12-3279-2012.

Tibaldi A. Contractional tectonics and magma paths in volcanoes. Journal of Volcanology and Geothermal Research, V. 176, No. 2, 2008, pp. 291-301.

Tibaldi A., Pasquarè F.A., Tormey D. Volcanism in reverse and strike-slip fault settings. In: New Frontiers in Integrated Solid Earth Sciences (ed. S. Cloetingh, J. Negendank), Springer-Verlag. 2010, pp. 315-348, DOI: 10.1007/978-90481-2737-5.

Veber M.V. Recherches preliminaries sur le tremblement de terre a Chamakha, Comptes Rendue des Seances, Tome I, Academie Imperiale des Sciences, St.-Petersbourg, 1904, pp. 238-241.

Walter T.R., Amelung F. Volcanic eruptions following $\mathrm{M} \geq 9$ megathrust earthquakes: Implications for the Sumatra-Andaman volcanoes. Geology, V. 35, No. 6, 2007, pp. 539-542.

Walter T.R., Wang R, Acocella V., Neri M., Grosser H., Zschau J. Simultaneous magma and gas eruptions at three volcanoes in southern Italy: An earthquake trigger? Geology, V. 37, No. 3, 2009, pp. 251-254.

Watt S.F.L., Pyle D.M., Mather T.A. The influence of great earthquakes on volcanic eruption rate along the Chilean subduction zone. Earth Planetary Science Letters, V. 277, No. 3-4, 2009, pp. 399-407. nesia. Marine and Petroleum Geology, V. 26, No. 9, 2009, pp. 1751-1765.

Mellors R., Kilb D., Aliyev A., Gasanov G., Yetirmishli G. Correlations between earthquakes and large mud volcano eruptions: Journal of Geophysical Research, V. 112, No. B04304, 2007, DOI: 10.1029/2006JB00448.

Nostro C., Stein R.S., Cocco M., Belardinelli M.E., Marzocchi W. Two-way coupling between Vesuvius eruptions and southern Apennine earthquakes, Italy, by elastic stress transfer. Journal of Geophysical Research, V. 103, No. B10, 1998, pp. 24,487-24,504.

Reilinger R.E., McClusky S.C., Vernant P., Lawrence S., Ergintav S., Cakmak R., Ozener H., Kadirov F., Guliev I., Stepanian R., Nadariya M., Hahubia G., Mahmoud S., Sakr K., Arrajehi A., Paradissis D., Al-Aydrus A., Prilepin M., Guseva T., Evren E., Dmirotsa A., Filikov S.V., Gomez F., Al-Ghazzi R., Karam G. GPS constraints on continental deformation in the Africa-Arabia-Eurasia continental collision zone and implications for the dynamics of plate interactions. Journal of Geophysical Research, V. 111, No. B5, 2006, DOI: 10.1029/2005JB004051.

Telesca, L. Babayev, G. Kadirov F. Temporal clustering of the seismicity of the Absheron-Prebalkhan region in the Caspian Sea area. Nat. Hazards Earth Syst. Sci., V. 12, No. 11, 2012, pp. 3279-3285, DOI:10.5194/nhess-12-3279-2012.

Tibaldi A. Contractional tectonics and magma paths in volcanoes. Journal of Volcanology and Geothermal Research, V. 176, No. 2, 2008, pp. 291-301.

Tibaldi A., Pasquarè F.A., Tormey D. Volcanism in reverse and strike-slip fault settings. In: New Frontiers in Integrated Solid Earth Sciences (ed. S. Cloetingh, J. Negendank), Springer-Verlag. 2010, pp. 315-348, DOI: 10.1007/978-90481-2737-5.

Veber M.V. Recherches preliminaries sur le tremblement de terre a Chamakha, Comptes Rendue des Seances, Tome I, Academie Imperiale des Sciences, St.-Petersbourg, 1904, pp. 238-241.

Walter T.R., Amelung F. Volcanic eruptions following $\mathrm{M} \geq 9$ megathrust earthquakes: Implications for the Sumatra-Andaman volcanoes. Geology, V. 35, No. 6, 2007, pp. 539-542.

Walter T.R., Wang R, Acocella V., Neri M., Grosser H., Zschau J. Simultaneous magma and gas eruptions at three volcanoes in southern Italy: An earthquake trigger? Geology, V. 37, No. 3, 2009, pp. 251-254.

Watt S.F.L., Pyle D.M., Mather T.A. The influence of great earthquakes on volcanic eruption rate along the Chilean subduction zone. Earth Planetary Science Letters, V. 277, No. 3-4, 2009, pp. 399-407.

\title{
ДИНАМИЧЕСКИЙ ТРИГГЕРНЫЙ ЭФФЕКТ ПРОЯВЛЕНИЯ ГРЯЗЕВЫХ ВУЛКАНОВ АЗЕРБАЙДЖАНА, ВЫЗВАННЫЙ КАСПИЙСКИМИ ЗЕМЛЕТРЯСЕНИЯМИ
}

\author{
Бабаев Г. ${ }^{1}$, Кадиров Ф. ${ }^{1}$, Тибальди А. ${ }^{2}$, Бонали Ф. ${ }^{2}$, Алиев Я. \\ ${ }^{1}$ Институт геологии и геофизики Национальной Академии наук Азербайджана \\ AZ1143, Баку, Азербайджан, просп. Г. Джавида, 119: babayev74@gmail.com \\ ${ }^{2}$ Университет Милан-Бикокка \\ 4, Пиациа делла Сиенза, Милан, 20126, Италия
}

Резюме. Существует несколько точек зрения о связи извержений грязевых вулканов с землетрясениями или проявлений землетрясений с извержениями грязевых вулканов. Статья посвящена оценке динамических напряжений, вызванных землетрясениями на Каспии, которые произошли 25 ноября 2000 года к югу от города Баку с магнитудами $\mathrm{M}_{\mathrm{w}} 6.1$ и 6.2. Мы исследовали связь между сейсмическим режимом и извержениями грязевых вулканов в Азербайджане, расположенных в зоне Шамахы-Гобустан-Абшерон. Также провели анализ динамики извержения более 30 грязевых вулканов на расстоянии более 100 км от ближних эпицентров Каспийских землетрясений во временном интервале - в течение пяти лет до и после таковых 2000 года. Расчеты динамической деформации показывают, что извержения всех вулканов в исследуемой зоне произошли в основном в результате триггерного эффекта Каспийского землетрясения. Большее количество извержений грязевых вулканов произошло на расстоянии более 50-60 км от эпицентров Каспийского землетрясения 2000 года. В течение 2-3 лет грязе- 
вые вулканы извергались на расстоянии 40 и 110 км от эпицентров. Через три года после проявления землетрясения на Каспии грязевые вулканы извергались на расстоянии более 70 км. Наибольшее количество извержений произошло в течение двух лет после землетрясения с наибольшей частотой проявления в шесть месяцев. Особенно надо отметить, что несколько извержений произошли в течение 8 месяцев от триггерного эффекта; после этого периода количество извержений в течение ряда месяцев имеет рассеянную и непериодичную частоту. Сравнение позволило сделать вывод, что динамические напряжения преимущественно связаны с триггерным эффектом, создающим условия для проявления событий с более высокой магнитудой, и, следовательно, извержения наблюдаются в течение 1-2 лет после землетрясений.

Ключевые слова: землетрясение, триггерный эффект, грязевой вулкан, динамическое напряжение, Азербайджан

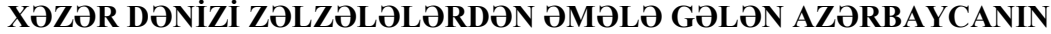 PALÇIQ VULKANLARI TOZAHÜRÜNÜN DİNAMIK TRİGGER EFFEKTİ
}

\author{
Babayev Q. ${ }^{1}$, Qədirov F. ${ }^{1}$, Tibaldi A. ${ }^{2}$, Bonali F. ${ }^{2}$, Oliyev Y. ${ }^{1}$ \\ ${ }^{1}$ Geologiya va geofizika Institutu, Azarbaycan Milli Elmlar Akademiyası \\ AZ1143, Bakl, Azarbaycan, H. Cavid prosp.119: babayev74@gmail.com \\ ${ }^{2}$ Milan-Bikokka Uuniversiteti \\ 4, Piazza della Scienza, Milan, 20126, Italiya
}

Xülasə. Palçıq vulkanlarının püskürməsinin zəlzələ ilə əlaqəsi və ya zəlzələlərin baş verməsinin palçıq vulkanlarının püskürməsi ilə bağlılığı barəsində bir neçə nəzər nöqtəsi mövcuddur. Məqalə, Bakı şəhərinin cənubunda 25 noyabr 2000-ci ildə Xəzər dənizində baş vermiş $M_{w} 6.1$ və 6.2 maqnitudalı zəlzələlərin yaratdığ 1 dinamik gərginliyin qiymətləndirilməsinə həsr olunub. Bu baxımdan, seysmik rejimlə Azərbaycanın Şamaxı-Qobustan-Abşeron ərazisində yerləşən palçıq vulkanlarının püskürməsi arasında olan əlaqənin tədqiqatını apardıq. 2000-ci ildə baș vermiș Xəzər zəlzələlərindən əvvəl və sonrakı beș il müddət ərzində həmin zəlzələlərin epimərkəzlərindən $100 \mathrm{~km}$ məsafədə olan 30-dan artıq palçıq vulkanının püskürmə dinamikası təhlil olunmuşdu. Dinamik deformasiyaların hesablamaları göstərdi ki, tədqiqat ərazisində olan bütün vulkanların püskürməsi, əsasən, Xəzər zəlzələlərinin trigger effekti nəticəsində baş vermişdi. Palçıq vulkanlarının daha çox püskürməsi 2000-ci il Xəzər zəlzələsin epimərkəzindən 50-60 km-dən artıq məsafədə müşahidə olunub. Palçıq vulkanlar epimərkəzdən 40 və $110 \mathrm{~km}$ məsafədə 2-3 il ərzində püskürürdü. Xəzər dənizində baş vermiş zəlzələdən üç il sonra isə, $70 \mathrm{~km}$-dən artıq məsafədə palçıq vulkanlarının püskürməsi qeydə alınmışdı. On çox püskürmə zəlzələdən sonra iki il ərzində, ən yüksək tezliklə - altı ay ərzində baş vermişdi. Xüsusilə,geyd etmək lazımdır ki, triger effekti nəticəsində bir neçə püskürmə 8 ay ərzində baş vermişdir, və bu müddətdən sonra püskürmə sayı bir neçə ay ərzində daha dağınıq və qeyri-periodik xüsusiyyət daşıyırdı. Müqayisəli təhlil nəticəsində belə gənaətə gəlmək olar ki, dinamik gərginliklər trigger effekti ilə əlaqədardır. Bu da öz növbəsində seysmik hadisələrin yüksək maqnituda ilə baş verməsi üçün şərait yaradır və püskürmələr zəlzələlərdən sonra 1-2 il ərzində müşahidə edilir.

Açar sözlor: zalzala, trigger effekti, palçıq vulkan, dinamik garginlik, Azarbaycan 